\title{
Omeprazole Magnesium
}

National Cancer Institute

\section{Source}

National Cancer Institute. Omeprazole Magnesium. NCI Thesaurus. Code C66256.

The magnesium salt form of a benzimidazole with selective and irreversible proton pump inhibitor activity. In the acidic compartment of parietal cells, omeprazole is protonated and converted into the active achiral sulfenamide; the active sulfenamide forms one or more covalent disulfide bonds with the proton pump hydrogen-potassium adenosine triphosphatase $(\mathrm{H}+/ \mathrm{K}+\mathrm{AT}$ Pase), thereby inhibiting its activity and the parietal cell secretion of $\mathrm{H}+$ ions into the gastric lumen, the final step in gastric acid production. $\mathrm{H}+/ \mathrm{K}+$ AT Pase is an integ ral membrane protein of the gastric parietal cell. 